\title{
ARTYKUtY
}

Klio. Czasopismo poświęcone dziejom Polski i powszechnym

PL ISSN 1643-8191, t. 45 (2)/2018, s. 37-59

(c) (1) $\Theta$

http://dx.doi.org/10.12775/KLIO.2018.018

ŁUKASZ WRÓBEL"

\section{Źródła do dziejów magnackiego rodu. O egodokumentach trzech pokoleń Hylzenów***}

\section{Archival sources to the history of the magnate family. About the egodocuments of three generations of Hylzen family}

Streszczenie: Celem niniejszego artykułu jest zaprezentowanie rodowej spuścizny rękopiśmiennej Hylzenów rozsianej po archiwach i bibliotekach Europy Środkowo-Wschodniej. $\mathrm{Na}$ źródła przechowywane w litewskich, łotewskich, ukraińskich i polskich instytucjach składają się dzienniki, korespondencja, testamenty, księgi typu silva rerum, a także genealogie należące do żyjących w XVIII wieku członków rodu: Jerzego Konstantego (1673-1737), Jana Augusta (1702-1767), Jerzego Mikołaja (1692-1775), Konstancji (zm. 1795), Józefa Jerzego (1736-1786), Anny Rozalii (zm. 1791) i Idziego (1772-1800). Dokumenty, w większości o charakterze egodokumentalnym, mają fundamentalne zna-

* Wydział Nauk Historycznych UMK, ul. Bojarskiego 1, 87-100 Toruń, luka.wrobel@gmail.com.

"Artykuł powstał w ramach realizacji projektu „Studium mentalności szlachty inflanckiej w XVIII wieku w świetle egodokumentów rodu Hylzenów", finansowanego przez Narodowe Centrum Nauki (Preludium 9), nr 2015/17/N/HS3/00829. 
czenie w procesie tworzenia dziejów wewnętrznych Hylzenów, gdyż pozwalają odtworzyć główne kierunki działalności politycznej, gospodarczej i kulturalnej rodu. Dzięki autobiograficznemu charakterowi samoświadectw materiały pozwalają również odtworzyć biografie poszczególnych przedstawicieli rodu.

Abstract: The purpose of this article is to present Hylzen manuscripts scattered throughout the archives and libraries of Central and Eastern Europe. The sources stored in Lithuanian, Latvian, Ukrainian and Polish institutions include diaries, correspondence, wills, silva rerum books, as well as genealogies belonging to members of the family living in the 18th century: Jerzy Konstanty (1673-1737), Jan August (1702-1767), Jerzy Mikołaj (1692-1775), Konstancja (d. 1795), Józef Jerzy (1736-1786), Anna Rozalia (d. 1791) and Idzi (1772-1800). The egodocumentary nature of documents is of fundamental importance in the process of creating internal history of Hylzens, because it allows to reconstruct the main directions of the political, economic and cultural activity of the family. Thanks to the autobiographical nature of self-evidences, the materials also allow to reproduce the biographies of individual representatives of the family.

Słowa kluczowe: szlachta; Inflanty; Hylzenowie; mentalność; egodokumenty.

Keywords: nobility; Livonia; Hylzen family; history of mentality; egodocuments.

\section{Cudia nad działalnością, życiem codziennym czy mentalnością magnaterii $\circlearrowleft$ Rzeczpospolitej Obojga Narodów należą do podstawowych badań histo- rycznych ${ }^{1}$. Mimo to szlachta inflancka, w tym Hylzenowie, nie doczekała się własnego opracowania ${ }^{2}$. Również żaden z członków rodziny nie był bohat-}

${ }^{1}$ W. Czapliński, J. Długosz, Żcie codzienne magnaterii polskiej w XVII wieku, Warszawa 1982; Wtadza i prestiz. Magnateria Rzeczypospolitej w XVI-XVIII wieku, red. J. Urwanowicz, E. Dubas-Urwanowicz, P. Guzowski, Białystok 2003; Patron i dwór. Magnateria Rzeczypospolitej w XVI-XVIII wieku, red. E. Dubas-Urwanowicz, J. Urwanowicz, Warszawa 2006; Fundator i mecenas. Magnateria Rzeczypospolitej w XVI-XVIII wieku, red. E. Dubas-Urwanowicz, J. Urwanowicz, Białystok 2011; Wobec króla i Rzeczpospolitej. Magnateria w XVI-XVIII wieku, red. E. Dubas-Urwanowicz, J. Urwanowicz, Kraków 2012.

${ }^{2}$ Oprócz monografii rodowych dysponujemy wieloma pracami poświęconymi elitom politycznym Wielkopolski, Rusi Czerwonej czy Prus Królewskich, natomiast poszczególne rodziny czy magnateria inflancka nie cieszą się zbytnim zainteresowaniem rodzimych historyków. Z prac podejmujących tę tematykę, jak i badania nad Hylzenami zob. Hülsen, [w:] Allgemeine Encyclopädie der Wissenschaften und Künste, sekcja 2, 
erem osobnej rozprawy ${ }^{3}$. Na niewielkie zainteresowanie rodziną mogło mieć wpływ kilka czynników. Hylzenowie aktywną rolę we wspólnocie politycznej Rzeczpospolitej Obojga Narodów zaczęli odgrywać dopiero w XVIII wieku. Od przybycia nad Bałtyk w XIII wieku aż do końca XVII stulecia rodzina związana była z Zakonem Niemieckim, a później z Księstwem Kurlandii i Semigalii, w łonie których zajmowała się służbą wojskową. Dopiero po rekatolizacji i polonizacji Hylzenowie zajęli się działalnością polityczną, która znacznie bardziej sprzyjała powstawaniu źródeł autobiograficznych. Ta jednak prowadzona była w województwie inflanckim, które nie cieszyło się specjalnym zainteresowaniem rodzimej historiografii. Kiedy natomiast w połowie XVIII wieku Hylzenowie przenieśli działalność polityczną do Wielkiego Księstwa Litewskiego, rozpoczęło się ich wygasanie, zakończone śmiercią ostatniego przedstawiciela rodu w 1800 roku.

$\mathrm{Na}$ niewielkie zainteresowanie Hylzenami wpłynął także charakter bazy źródłowej. Gromadzone przez kolejne pokolenia dokumenty, przywileje i królewskie nadania, źródła do dziejów Łatgalii, rodowa korespondencja przechowywane były $\mathrm{w}$ archiwum rodowym i liczącej w połowie XVIII wieku 20 tysięcy pozycji bibliotece ${ }^{4}$. Jednak wraz z wymieraniem

$H-N$, t. 11, Lipsk 1834, s. 490-491; G. Manteuffel, Hylzen, [w:] Wielka encyklopedia powszechna ilustrowana, t. 29-30, Warszawa 1902, s. 616-619; idem, O starodawnej szlachcie krzyżacko-rycerskiej na kresach inflanckich, „Miesięcznik Heraldyczny”, 1910, nr 6-7, s. 101-106; B. Dybaś, Uwagi na temat elity województwa inflanckiego w XVII-XVIII wieku, [w:] Wtadza i prestiz, s. 243-253; G. Manteuffel, „Inflanty Polskie” oraz "Listy znad Battyku”, oprac. K. Zajas, Kraków 2009; K. Zajas, Nieobecna kultura. Przypadek Inflant Polskich, Kraków 2008.

${ }^{3}$ Jeśli chodzi o literaturę przedmiotu poświęconą poszczególnym Hylzenom, to jak do tej pory powstały jedynie krótkie artykuły biograficzne, zob. J. Bartoszewicz, Znakomici mężowie polscy w XVIII wieku. Wizerunki historycznych osób, t. 2, Petersburg 1856, s. 199-260; idem, Hylzen (Jerzy Mikotaj), [w:] Encyklopedia powszechna, t. 12, Warszawa 1863, s. 375-380; idem, Hylzen (Jan August), [w:] ibidem, s. 380-384; idem, Hylzen (Józef), [w:] ibidem, s. 384-385; idem, Hylzen (Justynian), [w:] ibidem, s. 385; E. Rostworowski, Hylzen Jan August, [w:] Polski Stownik Biograficzny (dalej PSB), t. 10, Wrocław-Warszawa-Kraków 1962, s. 128-129; idem, Hylzen Jerzy Mikotaj, [w:] ibidem, s. 130; idem, Hylzen Józef Jerzy, [w:] ibidem, s. 130-133.

${ }^{4}$ B. Breżgo, Dawne biblioteki dworskie, [w:] Materiaty krajoznawczo-historyczne wydane w Daugawpilsie przez polsko-katolickie stowarzyszenie "Harfa”, Dyneburg 1938, s. 71-72. 
Hylzenów i kolejnymi podziałami majątku rodowa spuścizna stopniowo ulegała rozproszeniu i włączana była do bibliotek Platerów, Kossakowskich czy Działyńskich ${ }^{5}$. Negatywny wpływ na zachowanie rodowych źródeł miał fakt, że w ciaggu XIX i XX wieku zostały zniszczone siedziby rodu znajdujące się niegdyś w Dagdzie (Łotwa), Oświeju czy Belmoncie (Białoruś), a magnackie pałace w Warszawie, Gdańsku czy Wilnie trafiły w obce ręce.

Dlatego celem niniejszego artykułu jest zaprezentowanie rodowej spuścizny rękopiśmiennej Hylzenów rozsianej po archiwach i bibliotekach Europy Środkowo-Wschodniej. Większość źródeł do dziejów rodu ma charakter egodokumentalny ${ }^{6}$. Samo pojęcie egodokumentu zostało ukute przez holenderskiego historyka Jacoba Pressera ${ }^{7}$. Presser mianem tym określał każde ze źródeł historycznych, w których badacz ma do czynienia z podmiotem piszącym i opisywanym w formie „ja”, rzadziej „on”8. Tego typu sytuacja zachodzi w dziennikach, korespondencji, testamentach, księgach typu silva rerum czy prywatnych listach ${ }^{9}$. Teksty te są wyraźnie wypełnione

${ }^{5}$ Archiwum Główne Akt Dawnych w Warszawie (dalej AGAD), Archiwum Przezdzieckich (dalej APrzez.), sygn. C-27, k. 32v; P. A. Jeziorski, Źródta do dziejów potudniowo-wschodnich Inflant (późniejszych Inflant Polskich) w latach 1561-1600 w archiwach Rygi i Wilna, „Miscellanea Historico-Archivistica” 2013, t. 20, s. 69-70.

${ }^{6} \mathrm{Na}$ temat egodokumentów zob. R. Dekker, Introduction, [w:] Egodocuments and history: autobiographical writing in its social context since the middle ages, Rotterdam 2002, s. 7-20; M. Fulbrook, U. Rublack, In Relation: The 'Social Self' and Ego-Documents, "German History” t. 28, nr 3, s. 263-272; S. Roszak, Egodokumenty - kilka uwag o polskich i europejskich doświadczeniach historiograficznych oraz metodologicznych, „Biuletyn Polskiej Myśli Historycznej” 2013, t. 8, s. 27-42; Egodokumenty. Tradycje historiograficzne i perspektywy badawcze, red. W. Chorążyczewski, A. Pacevičius, S. Roszak, Toruń 2015.

${ }^{7}$ Niektórzy uczeni posługują się terminami: self-narratives, testimonies to the self, Selbstzengnisse („samoświadectwa”), por. M. Fulbrook, U. Rublack, op. cit., s. 263; S. Roszak, Archiwa sarmackiej pamięci. Funkcje i znaczenie rękopiśmiennych ksiag silva rerum w kulturze Rzeczypospolitej XVIII wieku, Toruń 2004, s. 21.

${ }^{8}$ R. Dekker, Jacques Presser's Heritage: Egodocuments in the Study of History, „Memoria y Civilización” 2002, nr 5, s. 13-14.

${ }^{9}$ Ibidem, s. 14. Na temat specyfiki każdego ze źródeł zob. A. Sajkowski, Diariusz, dziennik, [hasło w:] Literatura polska. Przewodnik encyklopedyczny, t. 1, A-M, red. J. Krzyżanowski i in., Warszawa 1984, s. 188; H. Dziechcińska, Diariusz, [hasło w:] Stownik literatury staropolskiej. Średniowiecze, renesans, barok, red. T. Michałowska, 
przeżyciami, myślami i uczuciami piszącego - mówią o losach jednostkowego człowieka. Właściwości te mają przechowywane w instytucjach litewskich, łotewskich, ukraińskich i polskich źródła po Hylzenach. Dzięki ich charakterowi możemy poznać mentalność rodu oraz zrekonstruować biografie poszczególnych jego przedstawicieli. Obok egodokumentów przedmiotem analizy niniejszego tekstu są także źródła gospodarcze (diariusze gospodarskie), mowy sejmowe, oracje, przekłady poetyckie oraz twórczość o charakterze religijnym. Tak różnorodne źródła pozwolą w przyszłości odtworzyć kulturę umysłową, a także główne kierunki działalności politycznej, gospodarczej i kulturalnej rodziny, mają zatem fundamentalną rolę w procesie tworzenia dziejów wewnętrznych rodu.

Pierwszym z Hylzenów, którego źródłami autobiograficznymi dysponujemy, jest Jerzy Konstanty $(1673-1737)^{10}$. Jerzy Konstanty pod koniec XVII wieku razem z kilkoma innymi przedstawicielami rodów pochodzenia niemieckiego (m.in. Borchami, Felkerzambami, Grothuzami, Wolffami, Korffami, Manteufflami, Mohlami czy Platerami) zdecydował się powrócić do katolicyzmu ${ }^{11}$. Służąc dworowi saskiemu, Jerzy Konstanty mnożył położone w Inflantach Polskich dobra, o czym świadczą liczne przywileje majątkowe ${ }^{12}$, a także zajmował się działalnością fundacyjną

Wrocław 1998, s. 163-165; A. Cieński, Pamiętniki, [w:] Stownik literatury polskiego Oświecenia, red. T. Kostkiewiczowa, Wrocław 1977, s. 456-457; idem, Pamiętnikarstwo polskie XVIII wieku, Wrocław 1981; H. Dziechcińska, Pamiętniki czasów saskich. Od sentymentalizmu do sensualizmu, Bydgoszcz 1999; B. Popiołek, „Woli mojej ostatniej testament ten...". Testamenty staropolskie jako źródto do historii mentalności XVII i XVIII wieku, Kraków 2009; S. Roszak, op. cit.

${ }^{10}$ Die Hülsen in den Ostseeländern, Latvijas Valsts vestures arhivs (dalej LVVA), Fond (dalej F.) 7402, Aprakst (dalej Ap.) 3, Lieta (dalej L.) 154, k. 1; Von Eckeln genannt Hülsen (Huelsen), LVVA, F. 1100, Ap. 14, L. 200, k. 1.

${ }^{11}$ J. Kolbuszewski, Kultura polska na Eotwie. Przesztość i teraźniejszość. Próba zarysu catosici, [w:] Polacy na Eotwie, red. E. Walewander, Lublin 1993, s. 50-51.

${ }^{12}$ Lietuvos valstybes istorijos archyvas (dalej LVIA), Fondas (dalej F.) 1276, Apraksas (dalej Ap.) 1, nr 1628, k. 2; LVIA, F. 1276, Ap. 1, nr 1629, k. 1; Dagda, [w:] Stownik geograficzny Królestwa Polskiego i innych krajów stowianskich (dalej SGKP), t. 1, red. F. Sulimierski, B. Chlebowski, W. Walewski, Warszawa 1880, s. 892-893. 
i misyjną w podległych mu starostwach i alodiach ${ }^{13}$. Przy tak energicznej działalności Jerzy Konstanty musiał prowadzić szeroką korespondencję, na ślad której niestety nie udało się natrafić. Nadzieję na dotarcie do egodokumentów Hylzena daje niedawno odnaleziona w Łotewskim Państwowym Archiwum Historycznym księga typu silva rerum. Prawdopodobne jest, że ta spisana po niemiecku księga rodowa wyszła właśnie spod ręki Jerzego Konstantego, choć ostatecznie zweryfikują to dalsze badania.

Ze źródeł egodokumentalnych pozostawionych przez Jerzego Konstantego mamy do czynienia z testamentem, a dokładnie zapisem wiecznej dyspozycji, który udało się odnaleźć w księgach grodzkich starostwa dyneburskiego (Fond 712). W sporządzonym 2 grudnia 1723 roku (oblatowanym 11 stycznia roku następnego) dokumencie zmęczony pracą i w podeszłym wieku Jerzy Konstanty zrzekł się praw do większości swoich majątków, czyli Dagdy, Bukmujży i Hermanowicz (zastawionych u Hylzena przez Sapiehów) ${ }^{14}$. Nie chcąc, aby gromadzone przez lata dobra uległy rozproszeniu (in divisionem multarum partium), testator w całości zapisał je młodszemu synowi, Janowi Augustowi (1702-1767). Zastrzegł jednak, że sukcesor ma wypłacić starszemu bratu i duchownemu, Jerzemu Mikołajowi (1692-1775), jednorazowo 2 tysiące bitych talarów oraz corocznie - 200 talarów, a siostrom wyznaczone wcześniej posagi. Obok tego Jerzy Konstanty podkreślił w dokumencie, że Jerzy Mikołaj „ma mieć wolną i spokojną residentia po wszystkich dobrach tak moich jako też już wydzielonych synowi memu JOMCi p. Janowi Hylzenowi"15. Po uczynieniu dyspozycji

13 A. Mariani, Jezuici $w$ Inflantach $i w$ Kurlandii (1700-1773). Między wielka polityka a elita lokalna, "Zapiski Historyczne” 2012, z. 4, s. 129; K. Ogle, The Evidences of the Activity of the Jesuits in the Architectural Heritage of Polish Livonia, [w:] Stan badań nad wielokulturowym dziedzictwem dawnej Rzeczypospolitej, t. 3, red. W. Walczak, K. Łopatecki, Białystok 2012, s. 438; G. Manteuffel, $Z$ dziejów starostwa marienhauskiego, „Kwartalnik Litewski” 1910, r. 1, t. 2, s. 31-32. O talentach gospodarskich Hylzena pisze P. A. Jeziorski, Dyneburg w ostatnim stuleciu istnienia Rzeczpospolitej Obojga Narodów. Przyczynek do dziejów spotecznych i gospodarczych miasta, [w:] Stan badań nad wielokulturowym dziedzictwem dawnej Rzeczypospolitej, t. 2, red. W. Walczak, K. Łopatecki, Białystok 2010, s. 435.

${ }^{14}$ LVVA, F. 712, Ap. 1, L. 77, k. 48.

15 Ibidem, k. 49-50v. 
majątkowych Jerzy Konstanty przeniósł się do Gdańska, gdzie spędził ostatnie lata w klasztorze oliwskim na dewocji i zmarł 13 listopada 1737 roku $^{16}$. Jerzy Konstanty oraz Anna Regina Schemelphenning von der Opje obok dwóch synów doczekali się trzech córek: Anny Matyldy, Jadwigi Karoliny i Eleonory ${ }^{17}$. Najstarsza z nich wstąpiła do wileńskiego zakonu benedyktynek przy kościele św. Katarzyny, gdzie przyjmowane były wyłącznie córki z najlepszych litewskich domów szlacheckich. Po kilku latach spędzonych we wspólnocie Anna Matylda została w 1746 roku wybrana i wyświęcona na przeoryszę wileńskich benedyktynek ${ }^{18}$. Jako przewodnicząca zgromadzenia energicznie prowadziła sprawy majątkowe zakonu, co wymagało częstej korespondencji, która częściowo zachowała się w Archiwum Radziwiłłowskim w Archiwum Głównym Akt Dawnych ${ }^{19}$. Znajdujące się $\mathrm{w}$ tym zbiorze listy z lat $1745-1750$ pokazują, $\mathrm{w}$ jaki sposób Matylda dbała o sprawy majątkowe zgromadzenia i jak starała się pozyskiwać protektorów (m.in. hetmana Michała Kazimierza Radziwiłła „Rybeńkę”). O energii i talentach literackich przeoryszy świadczą wydane przez nią utwory religijne i przekłady, wśród których znajdują się Krótkie zebranie dzielnego ćwiczenia w postępku duchownym wydane w 1749 roku w Wilnie oraz Reguta świętego ojca Benedykta z tacińskiego na polski język teraz pilniej, niż kiedy, przetożona (1756 rok) ${ }^{20}$. Cztery lata po opublikowa-

${ }^{16}$ W jednym z listów z 1729 roku Jan August pisze, że jego ojciec jest „comoranti we Gdańsku”, zob. J. A. Hylzen do K. Sapiehy, Dagda, 23 VIII 1729, Lietuvos mokslų akademijos Vrublevskiu biblioteka (dalej LMAB), F. 139-1101, k. 4v. Również w Gdańsku, a dokładnie w katedrze oliwskiej, Jerzy Konstanty został pochowany, do dziś zachował się tam jego grób, zob. Z. Iwicki, Nekropolia oliwska, Gdańsk 2004, s. 127.

17 Archivio Segreto Vaticano, I Archivio della Nunziatura in Varsavia, nr 189. Jadwiga Karolina (zm. przed 3 VIII 1741) wyszła za Jana Franciszka Szadurskiego (zm. 1755/1757), a Eleonora - za Stanisława Pereświta Sołtana (1698-1758), zob. T. Żychliński, Ztota księga szlachty polskiej, t. 2, Poznań 1880, s. 322; Z. Anusik, Sottan (Pereświet-Sottan) Stanistaw, [w:] PSB, t. 40, Warszawa-Kraków 2000-2001, s. 365.

18 „Kuryer Polski”, 1746, nr 525, Wilno 15 XII.

${ }^{19}$ M. Hylzen do M. K. Radziwiłła, AGAD, Archiwum Radziwiłłów (dalej AR) V, sygn. 5588, k. 1-15.

${ }^{20}$ A. Jocher, Obraz bibliograficzno-historyczny literatury $i$ nauk $w$ Polsce, t. 3, Wilno 1857, s. 16; A. Kaladžinskaite, Benediktiniškoji ikonografija Vilniaus Šv. Kotrynos bažnyčioje, [w:] Benediktiniškoji tradicija Lietuvoje, red. L. Jovaiša, Wilno 2008, s. 219; K. Čepiene, 
niu Reguty i po przeprowadzeniu prac remontowych kościoła św. Katarzyny Anna Matylda zmarła ${ }^{21}$.

Starszy z synów Jerzego Konstantego, Jerzy Mikołaj, podobnie jak siostra obrał karierę duchowną i po wyświęceniu przez kilka lat sprawował swoją posługę przy katedrze dyneburskiej22. W 1738 roku został regentem kancelarii wielkiej koronnej, w 1740 pisarzem wielkim litewskim, a w 1746 roku biskupem smoleńskim ${ }^{23}$. Znacznie większą karierę zrobił jego młodszy brat Jan August, który po powrocie z kilkuletniej podróży edukacyjnej zdobył uznanie szlachty na sejmiku dyneburskim ok. 1720 roku $^{24}$. Tak jak starszy brat, w 1738 roku został regentem (kancelarii wielkiej Wielkiego Księstwa Litewskiego), natomiast w 1744 roku wszedł do senatu jako kasztelan inflancki, a w 1754 roku został wojewodą mińskim i kawalerem Orderu Orła Białego ${ }^{25}$. Jan August pomnażał otrzymany od ojca majątek i zdobywał kolejne przywileje, które oprócz dużej fortuny przyniosły mu starostwa: marienhauskie, brasławskie (oba grodowe), parchowskie, omeliańskie i kazuńskie ${ }^{26}$.

Ożywiona działalność polityczna i majątkowa braci Hylzenów pozwoliła wynieść rodzinę ze statusu średnioszlacheckiego do magnackiego i - co ważne - sprzyjała powstawaniu wielu dokumentów, które zachowały się do dziś. Wśród nich należałoby zacząć od korespondencji, gdyż Hylzenowie stale używali tego środka komunikacji i należeli do kilku kręgów ko-

I. Petrauskiene, Vilniaus akademijos spaustuves leidiniai 1576-1805. Bibliografija, Wilno 1979, s. 188, 307; A. Pacevičius, Knygǔženklai ir ego-dokumentai senosios Lietuvos benediktiniu vienuolynu bibliotekose, [w:] Benediktiniškoji tradicija Lietuvoje, s. 170.

${ }^{21}$ J. J. Hylzen do K. Hylzen, VII 1760, LMAB, F. 9-7, k. 71.

${ }^{22}$ LVVA, F. 712, Ap. 1, L. 77, k. 48; J. Tumelis, Hylzenas Jurgis Mikalojus, [w:] Visuotine lietuviu enciklopedija, t. 7, Wilno 2005, s. 560; M. Ivanovič, Hylzen Jerzy Mikolaj, „Knygotyra”, 2002, t. 39, s. 173; A. Wieczorek, Zgromadzenia Księży Misjonarzy św. Wincentego a Paulo na terenie Rzeczypospolitej od potowy XVII do początku XIX wieku, Toruń 2014, s. 110; J. Bartoszewicz, Hylzen (Jerzy Mikotaj), s. 375-376.

${ }^{23}$ E. Rostworowski, Hylzen Jerzy Mikotaj, s. 130.

${ }^{24}$ J. Bartoszewicz, Znakomici mężowie polscy, s. 205.

${ }^{25}$ E. Rostworowski, Hylzen Jan August, s. 128-129.

${ }^{26}$ LVVA, F. 712, Ap. 1, L. 77, k. 48-54; Ksiegi Pieczętne (Sigillata), AGAD, Metryka Koronna (dalej MK), S 20, k. 18; Lustracja inflanckich starostw, LVVA, F. 712, Ap. 1, L. 347a, k. 4-37. 
respondencyjnych. Jak dowodzą listy znajdujące się w Bibliotece Zakładu Narodowego im. Ossolińskich we Wrocławiu, obaj bracia interesowali się polityką międzynarodową. Chcąc pozyskać łaskę dworu, Jerzy Mikołaj na początku lat czterdziestych monitorował dla Mniszchów sytuację polityczną w Księstwie Kurlandii i Semigalii, gdzie po wygaśnięciu dynastii Kettlerów na tronie książęcym obsadzani byli kolejni kandydaci, co wiązało się z konfliktami zbrojnymi i ożywionymi ruchami wojsk ${ }^{27}$. Natomiast kiedy duchowny opuścił Inflanty i udał się do Drezna, sprawami kurlandzkimi zajmował się Jan August ${ }^{28}$.

Stałymi korespondentami Hylzenów byli członkowie rodu Sapiehów. To im Jan August zawdzięczał swój awans na regenturę oraz przywileje królewskie na starostwo brasławskie czy kasztelanię inflancką 29 . Spora część korespondencji między Hylzenem a Sapiehami zachowała się w Bibliotece Litewskiej Akademii Nauk im. Wróblewskich i Lwowskiej Narodowej Bibliotece Ukrainy im. W. Stefanyka ${ }^{30}$. Co prawda, jej większość ma charakter kurtuazyjny czy okolicznościowy (życzenia bożonarodzeniowe lub wielkanocne), jednak niektóre listy wskazują na aktywność podejmowaną przez Hylzenów w Gdańsku (np. organizacja nowych siedzib czy spotkań towarzyskich) $)^{31}$.

Jerzy Mikołaj i Jan August pozostawali w bliskich stosunkach z braćmi Załuskimi $^{32}$. Bracia Hylzenowie należeli do współpracowników prowad-

${ }^{27}$ J. M. Hylzen do Mniszcha, Biblioteka Zakładu Narodowego im. Ossolińskich we Wrocławiu (dalej BOss.), sygn. 2694/II, k. 35-43v; J. M. Hylzen do J. Ogrodzkiego, 1746, Biblioteka Książąt Czartoryskich w Krakowie (dalej BCz.), sygn. 706, k. 113-115; J. M. Hylzen do J. Ogrodzkiego, po 1744, BCz., sygn. 706, k. 75-77.

${ }^{28}$ J. M. Hylzen do J. Ogrodzkiego, 1746, BCz., sygn. 706, k. 113-115; J. M. Hylzen do J. Ogrodzkiego, po 1744, BCz., sygn. 706, k. 75-77.

${ }^{29} \mathrm{Na}$ relację między obu rodami wpływały także znaczne pożyczki zaciągane przez Sapiehów u Hylzenów, zob. Sapiehowie. Materiaty historyczno-genealogiczne i majątkowe, t. 3, Petersburg 1894, s. 205-206; J. Bartoszewicz, Hylzen (Jerzy Mikotaj), s. 376.

30 Zob. J. A. Hylzen do Sapiehy, LMAB, F. 139-1103, k. 1-25; J. A. Hylzen do J. S. Sapiehy, Аьвівська національна наукова бібліотека України імені В. Стефаника (dalej LNBS), F. 103, nr 2231, 2300, 2303, 5120, 5129, 5257, 5258, 5361

31 J. A. Hylzen do Sapiehy, 28 VIII 1759, LMAB, F. 139-1106, k. 1.

32 Jerzy Mikołaj regenturę w kancelarii koronnej zawdzięczał Józefowi Andrzejowi, a w 1746 r. namawiał Andrzeja Stanisława na poparcie własnej kandydatury do zwol- 
zonej przez Załuskich biblioteki ${ }^{33}$. Nic zatem dziwnego, że w zbiorach Biblioteki Narodowej, gdzie przechowywana jest korespondencja Józefa Andrzeja i Andrzeja Stanisława, znajdujemy listy Hylzenów, z których możemy odtworzyć współpracę magnatów oraz udział Hylzenów w inicjatywach biblioteki. Wśród nich było chociażby Towarzystwo Czytelnicze - luźna organizacja zrzeszająca szlachtę o zainteresowaniach literackich ${ }^{34}$. Przynależąc do Towarzystwa, Hylzenowie odbierali książki od bibliotekarzy Załuskich i przesyłali je kolejnym szlachcicom. Krążące między Dagdą a Warszawą dzieła były starannie dobierane przez biskupa Jerzego Mikołaja, który dbał o to, aby trafiały do niego prace z historii Kościoła, dzieła historyczne i geograficzne, a jednocześnie pilnował, by te niezgodne z dogmatami katolickimi nie były przesyłane młodszemu bratu ${ }^{35}$.

Jerzy Mikołaj, jak na erudytę czasów saskich przystało, sam zajmował się twórczością literacką, a także edycją i przekładami utworów religijnych, których zestawienie możemy znaleźć w „starej” i „nowej” bibliografii Gabriela Korbuta ${ }^{36}$. W przeciwieństwie do pochłoniętego polityką brata,

nionego przez Jana Małachowskiego podkanclerstwa koronnego. Natomiast Jan August miał podróżować z braćmi Załuskimi po Francji w czasie swojej tury kawalerskiej, zob. J. M. Hylzen do J. Ogrodzkiego, Dagda, 17 V 1746, BCz., sygn. 706, k. 83; J. A. Załuski, Józefa Jędrzeja Zatuskiego biskupa kijowskiego i czerniechowskiego Biblioteka historyków, prawników, polityków i innych autorów polskich lub o Polsce piszących, wyd. J. Muczkowski, Kraków 1832, s. 75; E. Iwanowski, Kilka rysów i pamiątek, Poznań 1860, s. 345.

33 J. Kozłowski, Szkice o dziejach biblioteki Zatuskich, Wrocław-Warszawa-Kraków-Gdańsk-Łódź 1986, s. 36-38, 84-86; S. Roszak, Koniec świata sarmackich erudytów, Toruń 2012, s. 168, 173.

${ }^{34}$ J. Kozłowski, op. cit., s. 83-88.

${ }^{35}$ J. M. Hylzen do J. A. Załuskiego, 1744, Biblioteka Narodowa w Warszawie (dalej BN), sygn. III/3244, k. 59-62v; J. M. Hylzen do J. Ogrodzkiego, Dagda, 26 III 1746, BCz., sygn. 706, k. 119; J. M. Hylzen do A. K. Horaina, Dagda, 17 I 1759, Biblioteka Publiczna im. H. Łopacińskiego w Lublinie (dalej BŁ), sygn. 1753, k. 17v; J. M. Hylzen do J. A Załuskiego, BN, sygn. III/3250, k. 129-130; J. M. Hylzen do J. A Załuskiego, Dagda, 11 IV 1761, BN, sygn. III/3261, k. 47-52v; J. M. Hylzen do J. A. Załuskiego, Dagda, BN, sygn. III/3263, k. 97-100v.

${ }^{36}$ G. Korbut, Literatura polska od początków do wojny światowej. Książka podręczna informacyjna dla studiujących naukowo dzieje rozwoju piśmiennictwa polskiego, t. 2, Warszawa 1929, s. 19; Hylzen Jerzy Mikotaj, [w:] Bibliografia literatury polskiej - „Nowy Korbut”, t. 4, oprac. E. Aleksandrowska z zesp., Warszawa 1966, s. 508-510; Hylzen Jan 
Jerzy Mikołaj po wyświęceniu na biskupstwo smoleńskie miał niewiele obowiązków ${ }^{37}$. Jego godność miała w większości charakter tytularny, gdyż diecezja, oprócz małego skrawka, znajdowała się w egzulanckim województwie smoleńskim i nie zapewniała dochodów, nad czym sam zainteresowany wielokrotnie ubolewał ${ }^{38}$.

Obok korespondencji ważnym źródłem do dziejów rodu są mowy polityczne Jana Augusta Hylzena. W swoich barokowych perorach, które zachowały się w Swadzie polskiej i tacińskiej Jana Daneykowicza-Ostrowskiego, Hylzen jawi się jako lider sejmiku dyneburskiego i ostrożny polityk. Większość pozostałych po Hylzenie mów dotyczy bezkrólewia po śmierci Augusta II. Wówczas Jan August wyraźnie opowiedział się za kandydaturą Fryderyka Augusta II, którego starał się narzucić szlachcie inflanckiej, zlecając przedłożenie posłom inflanckim instrukcji, zgodnie z którą nie będą mogli głosować za Leszczyńskim ${ }^{39}$. Natomiast po podwójnej elekcji stwierdził, że szlachta inflancka nie powinna wyraźnie opowiadać się za żadną ze stron i poczekać na wyjaśnienie sytuacji ${ }^{40}$. Również na mających zakończyć wojnę domową sejmach pacyfikacyjnych Hylzen konsekwentnie uważał, że międzynarodowe położenie Rzeczpospolitej i okupacja wojsk rosyjskich zmuszają do przyjęcia kandydatury saskiej ${ }^{41}$. Obok mów

August, [w:] Bibliografia literatury polskiej - „Nowy Korbut”, t. 2, oprac. zespół pod kier. R. Pollaka, [Warszawa] 1964, s. 275-276.

37 Szczegóły i okoliczności wyświęcenia zob. J. M. Hylzen do J. Ogrodzkiego, BCz., sygn. 706, k. 104, 109-111; J. M. Hylzen do J. A. Załuskiego, Wilno, 28 XI 1744, BN, sygn. III/3244, k. 62; J. M. Hylzen do A. K. Horaina, Dagda, 7 I 1746, BE, sygn. 1753, k. 7 .

38 Smoleńsk, [w:] Encyklopedia wiedzy o jezuitach na ziemiach Polski i Litwy 1564-1995, oprac. L. Grzebień, Kraków 1996, 627; Diariusz sejmu z r. 1748, wyd. W. Konopczyński, Warszawa 1911, s. 34; E. Rostworowski, Hylzen Jerzy Mikotaj, s. 130.

${ }^{39}$ Mowa WJMCi pana Jana z Eklów Hylzena na sejmiku w Dyneburgu 1733, [w:] Swada polska i tacińska albo Miscellanea Oratorskie, t. 1, cz. 1, wyd. J. DaneykowiczOstrowski, Lublin 1745, s. 193.

${ }^{40}$ Mowa WJMCi pana Jana z Eklów Hylzena na sejmiku w Dyneburgu 1734, [w:] Swada polska, t. 1, cz. 1, s. 195.

${ }^{41}$ Mowa WJMCi pana Jana z Eklów Hylzena na sejmie w Warszawie, [w:] Swada polska, t. 1, cz. 1, s. 198-199; Mowa WJMCi pana Jana z Eklów Hylzena na sejmiku relationis po sejmie, [w:] Swada polska, t. 1, cz. 1, s. 200; Diariusz sejmu walnego sześćniedzielnego 
z okresu bezkrólewia zachowało się też kilka przemówień Jana Augusta wygłoszonych w czasie obejmowania urzędów, publicznych przysiąg czy z obrad Rad Senatu ${ }^{42}$.

Często perory wymagały nie lada praktyki i przygotowań. Tak jak wielu sejmikowych mówców, również Jan August prowadził podręczne zapiski w księdze typu silva rerum, odnalezione w Bibliotece Litewskiej Akademii Nauk im. Wróblewskich ${ }^{43}$. Rękopis najprawdopodobniej pochodzi z biblioteki Platerów. Sylwa spisana jest roboczym i niewyraźnym duktem pisma. Większość tekstu jest w języku łacińskim i francuskim, a autor rzadko przechodzi na polski. Już na pierwszy rzut oka widać, że księga powstawała przez lata i ma konstrukcję otwartą, o czym świadczą liczne puste strony. $\mathrm{Na}$ te zapisane składają się przydatne dla każdego oratora publicznego sentencje, wiersze, anagramy czy toposy, których znalezienie miał ułatwić odpowiedni indeks ${ }^{44}$. W rękopisie pojawiają się także zagadnienia pochodzące z wielu dziedzin nauki, jak chociażby ekonomii (np. Oeconomia novinulla) czy ziołolecznictwa ${ }^{45}$. Wśród tych ostatnich znajdujemy przepis czy raczej proporcje potrzebne do wykonania wyciągu z Panchymagogonu ${ }^{46}$. Dzięki dokładnym notatkom dowiadujemy się, że Hylzen używał m.in. ekstraktu z odchodów sporządzonego na podstawie przepisu pochodzącego z Basilica Chymica, podręcznika medycznego niemieckiego alchemika i profesora medycyny Oswalda Crolliusa ${ }^{47}$. Znajdujące się w sylwie kalendaria, wypisy z historii powszechnej czy epitafia, jak np. Epitaphium Jagellonidi, oddają historyczne inklinacje wojewody ${ }^{48}$. Sylwa

[...] 1738, [w:] Teka Gabryela Junoszy Podoskiego arcybiskupa gnieźnieńskiego, t. 4, wyd. K. Jarochowski, Poznań 1856, s. 372.

42 Rzeczy Jana Augusta Hylzena, LVIA, F. 1276, Ap. 1, nr 31, k. 3v; Podziękowanie za kasztelanię inflancka JW JMCi pana Hylzena, [w:] Swada polska, t. 1, cz. 1, s. 401.

43 J. A. Hylzen, Silva rerum, LMAB, F. 9-14.

${ }^{44}$ Ibidem, k. 62-66.

45 Ibidem, k. 45.

46 Ibidem, k. 52. Również Konstancja Plater, żona Jana Augusta, notowała przepisy lekarskie, zob. Hylzenowa Katarzyna z Platerów, Lekarstwo na suchoty, LMAB, F. 9-1959. Metodom tym poddawany był chociażby ich syn Józef Jerzy, kiedy w 1756 r. przechodził ospę i zażywał oparte na medycynie humoralnej leki.

47 O. Crollius, Basilica chymica, t. 1-3, Wenecja 1643.

48 J. A. Hylzen, Silva rerum, LMAB, F. 9-14, k. 6, 12, 15. 
zawiera kilka informacji z geografii i ustrojów państw zachodnich, spośród których najwięcej dotyczy Francji (od ogólnych porad dotyczących tego, jak poradzić sobie nad Loarą, do informacji szczegółowych dotyczących paryskich hoteli $)^{49}$. Sylwa zawiera także sporo podań ludowych z określonymi bohaterami, w których główną rolę odgrywają zwierzęta (małpa, kozioł), trefnisie czy przedstawiciele szlachty ${ }^{50}$.

Poza działalnością polityczną Jan August zarządzał dobrami odziedziczonymi po ojcu ${ }^{51}$. Z kilku przekazów wiadomo, że w swoich dobrach razem z bratem prowadził ożywioną działalność gospodarczą i cywilizacyjną: sprowadzał do Inflant księży misjonarzy, zakładał ochronki, zakony, budował kościoły i szpitale ${ }^{52}$. W swoich dobrach kazał także prowadzić misję cywilizacyjną i religijną wśród chłopów. Świadczy o tym chociażby „Memoriał, podług którego rewizja po dobrach czyniona być ma przez JMC p. komisarza edycji JW JMC p. Hylzena, kasztelana inflanckiego", który udało się odnaleźć w zbiorze „Miscellaneów historyczno-literackich z czasów panowania Augusta III” znajdujących się w Dziale Rękopisów Biblioteki Zakładu Narodowego im. Ossolińskich we Wrocławiu. Co prawda „Memoriał” nie ma charakteru egodokumentalnego, ale został sporządzony na polecenie Jana Augusta i pokazuje, jakim gospodarzem był wojewoda. W jego pierwszej części Hylzen nakazuje komisarzom sprawdzić pracę administratorów jego dóbr.

W pisaniu regestrów, czy dochowują ordynacji IMCinej, żeby nad pugilares, diariusz, księgę regestrów i inwentarz żadnych zgoła nie mieli karteluszków. W pugilares, bez którego nigdy być nie mają, zapisać się cokolwiek przez dzień zdarzy w gospodarstwie, a z nich zapis w wieczór w diariuszu, a z diariusza przynajmniej raz w tydzień wypiszą w regestra gospodarskie, cokolwiek do nich należy, to jest rozchodu i przychodu ${ }^{53}$.

49 Ibidem, k. 1-1v.

${ }^{50}$ Ibidem, k. 30-30v

51 J. Bartoszewicz, Literaci za czasów saskich (1744-1747 r.), „Kłosy” 1871, nr 292, s. 73 .

52 G. Manteuffel, Hylzen, [w:] Wielka encyklopedia powszechna ilustrowana, t. 29-30 , s. 618 .

53 Memoriat, podtug którego rewizja po dobrach czyniona być ma przez JMC p. komisarza edycji JW JMC p. Hylzena, kasztelana inflanckiego, BOss., sygn. 2788, k. 7. 
Obok skrupulatności administratorów komisarze mieli sprawdzić, czy dwór, kościoły i budynki dworskie są zabezpieczone od ognia i złodziei. Zarządcy majątków, jak i sami włościanie mieli również wykazywać się odpowiednią postawą duchową. Stąd Hylzen nakazał komisarzom sprawdzić, czy administratorzy

przestrzegają we dworze chwały Bożej i postanowionego codziennie z ludźmi nabożeństwa? Czy stają się zadość postanowienia, żeby dworni ludzie wszyscy cztery razy w rok spowiadali się i komunikowali jako to na Boże Narodzenie, na Wielkanoc, na Zielone Świątki i na Wniebowzięcie N[aj]św[iętszej] [Maryi] Panny ${ }^{54}$.

Ci spośród chłopów, którzy nie dość „pilnie” chodziliby do kościoła, mieli być karani 10 „plagami” i dodatkowym dniem pracy, natomiast za nieprzystąpienie do spowiedzi świętej - 50 „postronkami” ${ }^{5}$. Znacznie gorsza kara czekała tych, którzy dopuścili się „wróżenia” lub korzystania z usług czarownic czy magów - ci mieli być bici rózgami od stóp do głów, a w razie braku poprawy - przypalani ogniem ${ }^{56}$. Trudno powiedzieć, czy zalecenia odniosły odpowiedni skutek, faktem jednak było, że łatgalscy chłopi praktykowali pogańskie zwyczaje. Dlatego Jan August w swoich dobrach (Dagdzie, Bukmujży, Kownacie i Pyłdzie) w 1742 roku ustanowił misję jezuicką ${ }^{57}$. W 1749 roku na jej czele stanął Michał Roth, który uczył tamtejszych chłopów pisania, czytania, podstaw rachunków i katechizmu, czym po wielu latach zapracował na miano „Apostoła Łotwy” 58 .

Niedatowany dokument można przypisać także Józefowi Jerzemu, który w latach 1760-1767 również był kasztelanem inflanckim.

${ }^{54}$ Ibidem, k. 7.

55 Ibidem, k. 10.

${ }^{56}$ Ibidem.

${ }^{57}$ Kownata, [w:] SGKP, t. 4, red. F. Sulimierski, B. Chlebowski, W. Walewski, Warszawa 1883, s. 519; Dagda, [w:] Encyklopedia wiedzy o jezuitach, s. 117.

${ }^{58}$ L. Grzebień, Roth (Rott) Michat, [w:] PSB, t. 32, Wrocław-Warszawa-Kraków 1990, s. 292. 
Po śmierci Jana Augusta na czele rodu stanęła jego żona, Konstancja z Platerów (zm. 1795) ${ }^{59}$. Przy pomocy córki Anny Rozalii walczyła z pozostałymi członkami rodziny, skorymi do wzięcia „w opiekę” jej samej, jak i zostającego pod jej pieczą wnuka Idziego ${ }^{60}$. Będąc wdową, staropolskim zwyczajem Hylzenowa oddała się pod opiekę królowi i nieustannie zabiegała o jego łaski ${ }^{61}$. Interesowała się również życiem politycznym, a w szczególności wyrokami Trybunału Głównego Wielkiego Księstwa Litewskiego ${ }^{62}$. Dbała także o fundacje ustanowione przez Hylzenów i Platerów ${ }^{63}$.

Od 1767 roku Konstancja zarządzała ogromnym majątkiem rodowym znajdującym się nie tylko w Inflantach, ale także w Prusach Królewskich (starostwo parchowskie, pałac w Gdańsku), Koronie (starostwo kazuńskie) i Wielkim Księstwie Litewskim (pałac w Wilnie). Aby uporać się z licznymi dobrami, wdowa poleciła prowadzić dziennik przychodów i wydatków z wszystkich majątków ${ }^{64}$. Liczący 147 kart „Diariusz przychodu i rozchodu tak pieniędzy jako też i trunków” nie ma co prawda charakteru stricte egodokumentalnego, ale obok rozlicznych szczegółów z funkcjonowania magnackiej fortuny przynosi informacje autobiograficzne. Dokument pokazuje, że wojewodzina mińska była osobną bardzo mobilną. Doglądając rozległych majątków, nieustannie podróżowała i w tym celu ustanowiła na stałe grupę ludzi odpowiedzialnych za przejazd między Warszawą lub Gdańskiem, wśród których byli „sekretarz razem dyspozytor ludzi kuchni,

59 Przed 1767 r. nie dysponujemy wieloma informacjami na temat Konstancji. Po ślubie z Janem Augustem Konstancja urodziła czwórkę dzieci i zajęła się ich wychowaniem. W latach czterdziestych rozpoczęła starania o Order Krzyża Gwiaździstego, który otrzymała od cesarzowej Marii Teresy 3 maja 1747 r., zob. J. S. Dunin-Borkowski, Panie polskie przy dworze rakuskim (damy krzyża gwiaździstego, damy patacowe, kanoniczki honorowe sabaudzkie i berneńskie), Lwów 1891, s. 68-69.

${ }^{60}$ K. Hylzen do S. A. Poniatowskiego, Wilno, 12 IV 1787, BCz., sygn. 699, k. $747-$ -748 .

${ }^{61}$ K. Hylzen do S. A. Poniatowskiego, BCz., sygn. 699, k. 737-751v, sygn. 727, k. 377-389.

${ }^{62}$ K. Hylzenowa, Skrypta z jej ksiegi rachunkowej, LMAB, F. 9-1959, k. 1.

${ }^{63}$ K. Hylzen do A. M. Sapiehy, Warszawa, 3 II 1777, LMAB, F. 273-1190, k. 1.

${ }^{64}$ K. Hylzenowa z Platerów, Diariusz przychodu i rozchodu tak pieniędzy jako też i trunków ze wszystkich dóbr jaśnie wielmożnej JejMC pani Hylzenowej wojewodziny mińskiej sporządzony dnia szóstego m[iesia] ca junii roku 1767 w Wilnie, LMAB, F. 9-268, k. 3. 
oficer nadworny razem koniuszy" "65. Mimo licznych podróży Hylzenowa w przyszłości chciała osiąść w Wilnie. W tym celu poleciła wyremontować czy zbudować od nowa pałac Hylzenów na wileńskich Łukiszkach, czego dowodzą znajdujące się w „Diariuszu” kontrakty z cieślami, majstrami i murarzami, a także rachunki budowlane ${ }^{66}$.

„Diariusz” pokazuje także stałe zainteresowanie Konstancji administracją skarbowo-sądową prowadzoną w jej dobrach. Kiedy w grudniu 1767 roku w jednym z oświejskich folwarków niejaki Paposzka został oskarżony o zabójstwo niejakiego Szarkowicza, w diariuszu znalazł się dokładny opis postępowania administratorów folwarku. Mimo że śledczym nie udało się wskazać motywów zbrodni, to ustalono, iż Paposzka nie chciał zabić Szarkowicza „i tylko raz pociskiem go kijem uderzył, a nieboszczyk ucieczką salwując się, w biegu na kamienie upadł i śmiertelnie sobie piersi zbił tak dalece, że krew przez usta i uszy rzuciła się, a po tym w tydzień umarl” ${ }^{67}$. Tym samym „zwierzchność oświejska przysądziła Paposzce, ażeby zamiast ukarania gardła zapłacił nieodkładnie na mszą św. talarów 3 za duszę zmarłego, którego sukcesorom dał talarów 10. Przy tym był osmagany pięćdziesiąt razy publicznie"68.

Resztę diariusza wypełniają skrupulatnie tworzone co miesiąc zestawienia wydatków oraz zbiorów z dóbr Hylzenowej. Spośród nich mięsa (wołowina, baranina, drób, ryby), leguminy, rośliny korzenne oraz tytułowe trunki: wódki i piwa trafiają na pański stół. Wśród zestawień osobną grupę tworzą spisy ruchomości i płodów przekazywanych z Oświeja do Rzeszy czy z Wilna do Dagdy ${ }^{69}$. Dzięki nim dowiadujemy się, jakie srebra, kryształy, stroje, karety, sprzęty dla koni, a nawet stroje służby znajdowały się w pałacach Hylzenów ${ }^{70}$. Raporty finansowe uzupełniają mające formę gotowego i podpisanego kontraktu umowy zawierane z krawcami, spławnikami drewna, garncarzami czy karczmarzami.

\footnotetext{
${ }^{65}$ Ibidem.

${ }^{66}$ Ibidem, k. 7, 9, 11, 21v-22.

${ }^{67}$ Ibidem, k. 22v-23.

${ }^{68}$ Ibidem, k. 23.

${ }^{69}$ Ibidem, k. 12.

70 Ibidem, k. 12, 19-20.
} 
Kolejne pokolenie Hylzenów reprezentowane było przez Józefa Jerzego (1736-1786), Annę Rozalię (zm. 1791), Justyniana (1777) i nieznaną $\mathrm{z}$ imienia córkę, która zmarła w młodym wieku ${ }^{71}$. Spośród czworga potomstwa Jana Augusta i Konstancji największą karierę zrobił Józef Jerzy, który odziedziczył po ojcu nie tylko zmysł polityczny, ale również kulturę literacką, o czym świadczą pozostawione przez niego w znacznej liczbie źródła autobiograficzne. Ich przegląd warto rozpocząć od dzienników. Hylzen po zakończonej w 1752 roku edukacji domowej udał się na typowy i tradycyjny już dla rodu Grand Tour. Świadom ulotności własnej pamięci, a być może za nakazem Jana Augusta, który w młodości również podróżował, Józef Jerzy w czasie tury kawalerskiej prowadził diariusz. W ten sposób powstał liczący 283 karty „Diarium a discessu meo gedano Viennam 1752 15ma Septembris"72. Przechowywany w Bibliotece Uniwersytetu Wileńskiego dziennik w 2013 roku został wydany ${ }^{73}$ i doczekał się kilku opracowań ${ }^{74}$. Warto powiedzieć, że diariusz Hylzena to typowa dla epoki relacja z zagranicznej tury kawalerskiej. Jej narracja podyktowana jest kolejno zwiedzanymi przez Hylzena pod okiem Karola Wyrwicza państwami (Świętym Cesarstwem Rzymskim, Francją, Niderlandami Austriackimi i Republiką Zjednoczonych Prowincji), miastami (Wiedeń, Monachium, Paryż, Bruksela, Berlin),

7118 kwietnia 1753 r. Józef Jerzy Hylzen odnotował w swoim dzienniku, że otrzymał list od stolnika inflanckiego Jana Szadurskiego zawiadamiający o śmierci „małej siostry” na „afekcję gardłową”, zob. J. J. Hylzen, Juozapo Jurgio Hilzeno 1752-1754 metu keliones dienoraštis/Dziennik podróży Józefa Jerzego Hylzena z lat 1752-1754, wyd. J. Orzeł, A. Pacevičius, S. Roszak, Wilno 2013, s. 126.

${ }^{72}$ J. J. Hylzen, Diarium a discessu meo Gedano Viennam 175215 septembris, Vilniaus universiteto biblioteka (dalej VUB), F. 1-C160.

73 J. J. Hylzen, Juozapo Jurgio Hilzeno, Wilno 2013.

${ }^{74}$ J. Orzeł, A. Pacevičius, S. Roszak, Diariusz Józefa Jerzego Hylzena na tle pamiętników XVIII stulecia, [w:] J. J. Hylzen, Juozapo Jurgio Hilzeno, s. 22-58; J. Orzeł, Józef Jerzy Hylzen's Diary as an Example of an Ego-Document, [w:] Selbstzeugnisse im polnischen und deutschen Schriftum im Spatmittelalter und in der Fruhen Neuzeit (15.-18. Jahrhundert), red. R. Skowrońska, H. Flachenecker, R. Czaja, S. Roszak, J. Tandecki, Toruń 2014, s. 233-245; J. Orzeł, Kręgi towarzyskie Józefa Jerzego Hylzena w czasie jego europejskiej peregrynacji (1752-1754), [w:] Staropolskie podróżowanie, red. B. Rok, F. Wolański, Kraków 2016, s. 315-322; Ł. Wróbel, Obrazy europejskiej codzienności. Kultura ludowa w dzienniku podróży edukacyjnej Józefa Jerzego Hylzena z lat 1752-1754, [w:] Folklor - tradycja i wspótczesność, red. R. Sitniewska, E. Wilczyńska, V. Wróblewska, Toruń 2016, s. 75-88. 
wsiami, gospodami, a także podejmowanymi w czasie dłuższych postojów aktywnościami edukacyjno-towarzyskimi.

Po powrocie do kraju w 1754 roku Józef Jerzy rozpoczął karierę publiczną, ale nie zaprzestał spisywania swoich dziejów. Kończąc dziennik podróży, młody magnat rozpoczął dziennik „osiadły” - „Kontynuację diariusza od roku $1754 \mathrm{~m}$ [iesią]ca augusta 25 dnia we Gdańsku"75. Również przechowywany w Bibliotece Uniwersytetu Wileńskiego rękopis to obraz pierwszych lat kariery politycznej Józefa Jerzego ${ }^{76}$. Na jego 232 kartach obserwujemy coraz żywsze zainteresowanie młodego szlachcica najpierw lokalną, a później krajową polityką i stopniowe przechodzenie od biernego obserwowania do aktywnego partycypowania w kolejnych sejmikach i trybunałach. Źródło wypełniają również informacje z życia towarzyskiego dworu królewskiego, które Hylzen jako szambelan Augusta III obserwował z bliska, a także wieści z toczącej się w Europie wojny siedmioletniej (kolejne fazy, bitwy i dowódcy konfliktu) ${ }^{77}$. „Kontynuację” zamyka wpis z 20 maja 1759 roku, kiedy to zwolniony ze służby dworskiej Hylzen znajduje się w drodze powrotnej do Inflant, co pozwala uznać rękopis za zakończony.

W 1760 roku Józef Jerzy Hylzen zdobył nominację na kasztelanię inflancką, a tym samym wszedł do senatu. W 1767 roku udało mu się awansować na zwolnione po śmierci ojca województwo mińskie, a także zostać marszałkiem Trybunału Głównego Wielkiego Księstwa Litewskiego. Apogeum znaczenia politycznego Hylzen osiągnął w 1770 roku wraz z otrzymaniem województwa mścisławskiego. Nie wiemy, czy w tym czasie magnat w ogóle prowadził dziennik, czy ten po prostu nie zachował się do

${ }^{75}$ J. J. Hylzen, Kontynuacja diariusza od roku 1754 m[iesia]ca augusta 25 dnia we Gdańsku, VUB, F. 1-D1124.

${ }^{76}$ Ł. Wróbel, J. Orzeł, Józef Jerzy Hylzen (1736-1786) jako przedstawiciel elity inflanckiej. Studium początków kariery magnackiej, [w:] Spoteczeństwo staropolskie. Seria nowa. Spoteczeństwo a elity, t. 5, red. I. M. Dacka-Górzyńska, A. Karpiński, M. Nagielski [w druku].

77 Ł. Wróbel, Życie towarzyskie i rozrywki mtodego magnata $w$ świetle „Kontynuacji Dyaryusza od Roku 1754" Józefa Jerzego Hylzena, [w:] Staropolskie podróżowanie, s. 323-332; Ł. Wróbel, Józef Jerzy Hylzen jako diarysta. „Kontynuacja diariusza od roku 1754 miesiąca augusta 25 dnia we Gdańsku", [w:] Egodokumenty. Tradycje historiograficzne, s. 79-93. 
dziś. Niemniej jednak duża aktywność polityczna wymagała licznych kontaktów i prowadzenia stałej korespondencji. Tę magnat przed wysłaniem i po odbiorze wpisywał do osobnego brulionu, który autorowi udało się odnaleźć w Dziale Ogólnym BLAN ${ }^{78}$. Już podobna do dzienników formuła tytulacyjna - „Zbiór listów moich 1756 17ma septembris mca we Gdańsku" - wskazuje, że mamy do czynienia z korespondencją Hylzena. Atrybucję naturalnie potwierdza sama treść. Składający się z prawie 200 listów pisanych nieprzerwanie i wbrew tytułowi od roku 1755 do 1770 brulion to obraz wspomnianych wyżej awansów i działalności politycznej Hylzena ${ }^{79}$.

Obok listów do „Zbioru” trafiały także mowy wygłaszane przez Hylzena w szczególnie ważnych momentach kariery: przy zagajaniu sejmików, w czasie przewodniczenia obradom Trybunału Głównego Wielkiego Księstwa Litewskiego czy na Radach Senatu. Spośród 11 przemówień kilka zachowało się w innych źródłach, stąd możemy uznać, że mają one charakter ostateczny i są charakterystyczne dla stylu Hylzena ${ }^{80}$. Wśród nich warto zacytować mowę wygłoszoną przez magnata na pożegnanie obrad sejmiku deputackiego powiatu brasławskiego:

Jak godne tak chwalebne, tak przykładne prześwi[etneg]o powiatu ku dobru publicznemu i własnemu honorowi operacje w zgodnym IMPP sędziów na Trybunał Gł[ów]ny przybrania i ogłoszenia merentur od wszystkich aplauz i pochwał, ode mnie zaś w szczególności niezmierne dzięki obowiązki i wdzięczności, że prześwietny powiat tak łaskawie wspierać raczył usiłowania moje do sukcesu sejmiku ściągające się. Mam zatem honor powinszować z serca powiatowi prześwietnemu przybranych tak godnych deputatów, a teraz w zupełności ukontento-

${ }^{78}$ J. J. Hylzen, Zbiór listów moich 175617 ma septembris m[iesia]ca we Gdańsku, LMAB, F. 9-7.

${ }^{79}$ Tak jak dzienniki, również większość korespondencji prowadzona była w języku polskim. Jedynie listy do stryja Jerzego Mikołaja, Henryka Brühla lub innych członków dworu pisane były po francusku.

${ }^{80}$ Mowa JWJM pana Hilzena kasztelana inflanckiego na senatus consilium roku 1762 miana, Biblioteka Uniwersytecka w Warszawie, sygn. 122, k. 69-72 oraz Biblioteka Raczyńskich w Poznaniu, sygn. 376, k. 231-234; Mowa jaśnie wielmożnego JMCi pana hrabi Hilzena, AGAD, Zbiór Popielów, sygn. 364; Mowa JWJP Józefa hrabi na Oświeju, Dagdach Hilzena [...] miana w Mińsku żegnajac Trybunat r. 1768 ie 11 junii, BOss., sygn. 12770/II, k. 215. 
wania żegnam sejmik deputacki, a do zagajenia gospodarskiego przystępując, przekładam na wprzód WMM panom potrzebę, ażebyśmy w powszechnych uciskach naszych od Moskwy do Petersburga, prosząc o ulgi udali się i na tych IchMCiów, którzy za nami tam mówić będą [?] uchwałą wyznaczyli, co wszystko do wysłuchania i aprobaty poddaję ${ }^{81}$.

Z korespondencji rozproszonej, która nie znalazła się w brulionie lub powstała później, należy powiedzieć o listach Józefa Jerzego Hylzena kierowanych w dobie konfederacji barskiej i przewodnictwa w Trybunale Głównym do Michała Fryderyka Czartoryskiego, Jacka Ogrodzkiego i Stanisława Augusta ${ }^{82}$. Spore znaczenie dla biografii wojewody mają także listy pisane do Sapiehów i Karola Stanisława Radziwiłła. Epistoły kierowane do Sapiehów wypełniają głównie prośby o protekcje potrzebne przy awansie ${ }^{83}$, natomiast korespondencja z „Panem Kochanku” to obraz zaciekłego sporu o dzierżawę klucza dryświackiego prowadzonego przez Hylzena w ostatnich latach życia ${ }^{84}$.

Niestety, po młodszej siostrze Józefa Jerzego, Annie Rozalii (zm. 1791), nie zachowało się tak wiele źródeł ${ }^{85}$. W ogóle o samej Hylzenównie niewiele wiadomo. Wydaje się, że jej narodziny można datować około 1740 roku. Po domowym wychowaniu Anna Rozalia oddana została na dwór Augusta III, gdzie zdobywała należyty polor we fraucymerze królowej Marii Józefy. Kiedy w 1754 roku starania o rękę Hylzenówny rozpoczął Michał Ksawery Sapieha, królowa sprzeciwiła się temu dogodnemu dla Hylzenów mariażo-

81 J. J. Hylzen, Zbiór listów moich, LMAB, F. 9-7, k. 165v-166.

${ }^{82}$ Korespondencja Józefa Hylzena, woj. mińskiego i marszatka Trybunatu WKL, Biblioteka Jagiellońska w Krakowie, sygn. 6711; BCz., sygn. 665, 718, 799, 862, 666, 727, 966, 1693, 1951.

${ }^{83}$ LMAB, F. 139, sygn. 1103, 1106, 1107, 1108.

${ }^{84}$ AGAD, AR V, sygn. 5586, 5590. Przed śmiercią Hylzen zdążył sporządzić filantropijny testament, zob. Testament Józefa Hylzena, wojewody mścistawskiego, przeznaczającego potowę dochodów ze wszystkich dóbr swoich na edukację i mitosierne uczynki, „Dzieje Dobroczynności Krajowej i Zagranicznej z Wiadomościami ku Wydoskonaleniu jej służącymi” 1821 , r. 2.

85 Anna Rozalia zmarła 12 września 1791 r., o czym dowodzi list jej matki Konstancji do króla, zob. K. Hylzen do S. A. Poniatowskiego, 13 IX 1791, BCz., sygn. 727, k. 389. 
wi i wysłała swoją dwórkę do Saksonii ${ }^{86}$. Po powrocie do kraju siostra Józefa Jerzego została wydana w 1759 roku za Pawła Mostowskiego ${ }^{87}$. Mimo trojga potomstwa małżeństwo nie było udane. Mostowski w wyniku aktywnego poparcia dla konfederacji barskiej i fantastycznych planów, m.in. detronizacji i zgładzenia Stanisława Augusta, od 1770 roku znajdował się poza krajem bez możliwości powrotu ${ }^{88}$. Jak dowodzą listy znajdujące się w Bibliotece Książąt Czartoryskich, pozostawiona samej sobie Hylzenówna po nieudanych próbach przebłagania władcy zdecydowała się odciąć od męża i oddać pod królewską opiekę, która zapewnić jej miała zachowanie majątków po mężu banicie ${ }^{89}$. Kiedy Annie Rozalii udało się rozwiązać własne sprawy majątkowe, zajęła się zabieganiem u króla o poparcie w interesach matki i synów ${ }^{90}$.

Spośród trojga Hylzenów najgorzej przedstawia się spuścizna po Justynianie (ok. 1745-1778). Życiorys młodszego z synów Jana Augusta Hylzena da się odtworzyćc ${ }^{1}$, jednak nie dysponujemy jakimikolwiek źródłami pozostawionymi przez niego. Część z nich się nie zachowała, a inna nie mogła powstać, gdyż Justynian zmarł przedwcześnie w 1777 roku i nie zrobił takiej kariery jak ojciec i starszy brat ${ }^{92}$. Mimo tego Hylzenowi udało

86 Sapiehowie. Materiaty historyczno-genealogiczne, s. 394-402; J. J. Hylzen, Kontynuacja diariusza, k. 6.

${ }^{87}$ Księgi Wpisów (Libri Inscriptionum), AGAD, MK 232, k. 3v-6; J. J. Hylzen, Kontynuacja diariusza, k. 49-50.

88 W. Konopczyński, Mostowski Pawet Michat, [w:] PSB, t. 22, Wrocław-WarszawaKraków-Gdańsk 1977, s. 69-70.

${ }^{89}$ A. Mostowska do S. A. Poniatowskiego, 24 II 1781, BCz., sygn. 673, k. $435-$ -436v; A. Mostowska do S. A. Poniatowskiego, III 1781, BCz., sygn. 673, k. 437-438.

90 A. Mostowska do S. A. Poniatowskiego, 5 II 1782, BCz., sygn. 673, k. 440-441; A. Mostowska do S. A. Poniatowskiego, BCz., sygn. 927, k. 1048; A. Mostowska do S. A. Poniatowskiego, 8 X 1790, BCz., sygn. 734, k. 837.

${ }^{91}$ J. Bartoszewicz, Hylzen (Justynian), s. 385; Hylzen Justynian, [w:] S. Orgelbranda Encyklopedia powszechna z ilustracjami i mapami, t.7, Warszawa 1898, s. 224.

${ }_{92}$ Rękopism X. Bagińskiego dominikanina prowincji litewskiej (1747-1784 r.), wyd. E. Tyszkiewicz, Wilno 1854, s. 93. 
się w 1771 roku ożenić z Katarzyną Działyńską (1751-1774) i pozostawić po sobie potomka ${ }^{93}$.

Przy bezdzietności Józefa Jerzego to właśnie Idzi (1772-1800) - jako syn Justyniana i Katarzyny Działyńskiej - był ostatnim przedstawicielem i spadkobiercą Hylzenów. Osierocony przez oboje rodziców, od najmłodszych lat znajdował się pod opieką babki Konstancji. Opieka ta była konieczna również po osiągnięciu pełnoletniości, gdyż Idzi - prawdopodobnie - od urodzenia był upośledzony umysłowo ${ }^{94}$. Mimo tego babka starała się, aby otrzymał odpowiednie do magnackiego statusu wykształcenie, dlatego około 1791 roku wysłała go w zagraniczną turę kawalerską, której jednym z etapów był dłuższy postój w Szwajcarii. Tam Idzi miał zwiedzać kraj i ratować zdrowie. Pozostając za granicą, pisał także do babki oraz kuzynów Działyńskich listy, które zachowały się w Bibliotece Kórnickiej95. Równocześnie stałą korespondencję z babką i Działyńskimi podtrzymywał jego guwerner, Silvestre de Bellons ${ }^{96}$. Po powrocie do kraju Idzi nie zrobił wielkiej kariery i zmarł w 1800 roku.

Kwerenda archiwalno-biblioteczna poświęcona Hylzenom pozwoliła zebrać źródła do historii rodu oraz poczynić nowe ustalenia na temat karier poszczególnych członków, jak i dziejów całego rodu. Od Jerzego Konstantego, który związał się z dworem Augusta II, obserwujemy stały awans Hylzenów w hierarchii szlacheckiej. Dzięki odpowiednim zapisom testamentowym Jan August i Jerzy Mikołaj osiągnęli rangę magnacką, cze-

${ }^{93}$ Biblioteka Polskiej Akademii Nauk w Kórniku (dalej BK), sygn. 48; S. K. Potocki, Genealogia kórnickiej linii Dziatyńskich, „Pamiętnik Biblioteki Kórnickiej” 1976, z. 12, wklejka; W. Dworzaczek, Genealogia. Tablice, Warszawa 1959, nr 115, Działyńscy h. Ogończyk; Akta grodzkie warszawskie, AGAD, F. 103, s. 1543; Dowody do genealogii domu JJWW Dziatyńskich, BK, sygn. 475.

${ }_{94}$ Katarzyna II do M. Grimma, Petersburg, 20 IX 1783, Sbornik Imperatorskago Russkago istoricheskago obshchestva, t. 23, Petersburg 1878, s. 284; W. Kaliński, Dziennik 1787-1788, oprac. Ł. Kurdybacha, Wrocław 1968, s. 30; H. Błędowska, Pamiątka przesztości. Wspomnienia z lat 1794-1832, oprac. K. Kostenicz, Z. Makowiecka, Warszawa 1960, s. 180 .

${ }^{95}$ I. Hylzen do I. Działyńskiego, BK, sygn. 7270, k. 135.

96 A. Jakuboszczak, Ami de voyage w drugiej potowie XVIII wieku. Silvestre de Bellonstowarzysz w zagranicznej podróży edukacyjnej Ignacego Dziatyńskiego, [w:] Źródta do dziejów staropolskich podróży edukacyjnych, red. D. Żołądź-Strzelczyk, M. E. Kowalczyk [w druku]. 
go potwierdzeniem były ich krzesła senatorskie. Awans rodu potwierdzają kontakty towarzyskie. Obaj Hylzenowie podtrzymywali więzi nie tylko $\mathrm{z}$ rodami inflanckimi, ale z dworem oraz magnaterią z całej Rzeczpospolitej, przeto należeli do wielu kręgów korespondencyjnych. Korespondowali z Mniszchami, Sapiehami czy Załuskimi, co z pewnością było wysoko cenione i korzystne ${ }^{97}$. Ponadto relacje z Załuskimi, jak również własna twórczość (religijna i świecka) pokazują wysoką kulturę literacką rodu. Dzięki kolejnym nadaniom i odpowiedniej polityce gospodarczej Jana Augusta i Konstancji kolejny przedstawiciel rodu - Józef Jerzy - rozpoczął swoją karierę już jako pełnoprawny magnat. Status ten potwierdzają źródła dotyczące edukacji i rozległej aktywności politycznej oraz towarzyskiej wojewody mińskiego i mścisławskiego. Wraz z nim Hylzenowie osiągnęli apogeum znaczenia w połowie lat siedemdziesiątych XVIII wieku. Po 1775 roku rozpoczął się stopniowy upadek rodu. Wpływ nań miał pierwszy rozbiór. W jego wyniku rodzina straciła część majątku położonego w Księstwie Inflanckim, choć w dalszym ciągu dysponowała dobrami w województwie wileńskim. Na przeszkodzie dalszemu awansowi stanęły jednak czynniki natury demograficznej. Józef Jerzy nie pozostawił po sobie potomka, a jego młodszy brat Justynian spłodził upośledzonego umysłowo syna. Ten, mimo ożenku, nie był w stanie mieć potomstwa i wraz z jego śmiercią ród wygasł w 1800 roku. Tym samym rodowa Dagda, a także pielęgnowane i rozwijane kolejno przez Hylzenów majątki trafiły w ręce Platerów, Mostowskich i Działyńskich ${ }^{98}$. Razem z nimi przekazane zostały rodowe archiwa zawierające omówione egodokumenty i źródła gospodarcze, które stopniowo są scalane.

${ }^{7}$ W. Jurkiewicz, Korespondencja elit Polski stanistawowskiej: analiza wybranych kręgów korespondencyjnych, Bydgoszcz 1992, s. 8.

98 Jeszcze za życia Idziego część majątku przekazana została kuzynom Tadeuszowi, Józefowi i Mariannie Mostowskim i „opiekującemu” się nim w ostatnich latach Kazimierzowi Konstantemu Platerowi, zob. AGAD, APrzez., sygn. C-27. 